\title{
Türkçe ve Almanca İlköğretim Ana Dil Ders Kitaplarında Toplumsal Cinsiyete Bir Bakış
}

\author{
DOI: $10.26466 /$ opus.544676
}

\section{Rüveyda Hicran Çebi Kozallık* - Birkan Karg1 ${ }^{* *}$}

* Arş. Gör. Ondokuz Mayıs Üniversitesi, Eğitim Fakültesi, Kurupelit / Samsun / Türkiye E-Posta: ruveyda.cebi@omu.edu.tr ORCID: $\quad$ 0000-0001-9451-7040

**Prof. Dr. Ondokuz Mayıs Üniversitesi, Eğitim Fakültesi, Kurupelit / Samsun / Türkiye E-Posta: $\underline{\text { bkargi@omu.edu.tr }}$

ORCID: $\quad \underline{0000-0003-3242-3385}$

\section{Öz}

Bu çalışmanın amacı Türkiye'de ana dil Türkçe derslerinde kullanılan ders kitapları ile Almanya'da Baden Wüttenberg eyaletinde ana dil Almanca derslerinde okutulan ders kitaplarını" "toplumsal cinsiyet" bakış açısını ortaya koymak, benzerlikleri ve farklllıkları ortaya koymaktır. Araştırma için bireylerin kimlik gelişiminin önemli olduğu yaş aralı̆̆ıı kapsayan ilköğretim 2. 3. 4.ve 5. Sinıf Almanca ve Türkçe ders kitaplan seçilmişstir. Bu kitaplar ilköğretim Türkçe 2. 3. 4. Ve 5. Sinıf ders kitapları ile Niko Sprachbuch 2-3-4 ve 5 sinıf Deutsch kombi plus'tır. Veriler nitel içerik analizi yöntemiyle elde edilmiştir. Ders kitapları aile içi ve dişı roller, meslek rolleri ve cinsiyet rolleri olmak üzere dört ana başlık altında incelenmiştir. Türkçe ders kitaplarında erkek egemenliği net bir şekilde görülürken, Almanca ders kitaplarında metinlerin yansız, görsellerdeki kız ve erkek çocuk resim sayılarının birbirine yakın olduğu hatta kız çocuklarımın kitaplarda yer yer daha fazla yer aldığı tespit edilmiştir. Ayrıca, Almanca ders kitaplarında kız çocuklarının toplumda dezavantajlı görülebileceği spor tercihleri, ev içi işler ve roller, meslek seçimi gibi alanlarda desteklendiği ortaya çıkarılmıştır. Buna karşın Türkçe ders kitaplarının kız çocuklarına yeterli düzeyde yer vermediğgi çıkan sonuçlar arasındadır.

Anahtar Kelimeler: Ana dil, Türkçe ve Almanca ders kitapları, Deutsch Kombi Plus, ders kitaplarinda toplumsal cinsiyet 


\title{
An Overview of Gender in Primary School Textbooks Written in Turkish and German as Mother Tongue
}

\begin{abstract}
The aim of this study is to present the "gender" perspectives and to find out the similarities and differences of the textbooks used in Turkish courses in Turkey and the textbooks taught in German courses in Baden Wüttenberg, Germany. German and Turkish textbooks of 2, 3, 4 and 5. grades, which cover the important age range of identity development, are selected for the study. These are primary school Turkish 2.,3.,4. and 5 grade textbooks and Niko Sprachbuch 2-3-4- and 5 grade Deutsch Kombi Plus. The textbooks have been analysed through the items of domestic and non-domestic roles, professional roles and gender roles under five main topics. The results of the research suggest that there have been significant differences. In Turkish textbooks, there is a remarkable male dominance while in German textbooks it has been detected that texts are unbiased, that the number of visuals of boys and girls are equal, and that sometimes girls play a greater part in the textbooks. Furthermore, in German textbooks, it is found out that girls are supported more in the areas where they might be seen disadvantageous in society. On the other hand, it is concluded that Turkish textbooks do not provide adequate coverage for girls.
\end{abstract}

Keywords: Mother Tongue, Turkish and German Textbooks, Deutsch Kombi Plus, Gender in Textbook 


\section{Giriş}

İnsanlar sosyal bir ortamda doğarlar ve yaşamlarını bu sosyal düzene göre sürdürürler. Sosyal hayatların kendilerine özgü yaşam şekillerinin olması doğaldır. Çocukluktan itibaren kazanılan toplumsal cinsiyet yargıları, bireylerin sınırlarını belirlemektedir. Bu sinırlar, bireylerin neleri yapıp yapamayacağından, hangi davranışları benimseyip hangilerini ötekileştirmeleri gerektiğine kadar geniş bir alanı kapsamaktadır. Bu alan belirlenirken çocukluktan itibaren aile ve çevre gözlemlenerek ilk intibalar oluşturulmaktadır. Daha sonraları reklamlar ve çizgi filmler ile roller fark ettirilmeden benimsetilmeye çalışılmaktadır. Bireyler, okul çağına geldiklerinde ise toplumsal rolleri konusunda televizyon programlarının yanında ders kitapları da yerini almaktadır. Ders kitapları eğitim işlevinin yanı sıra bireylere birçok konuda gizil olarak önderlik etmekte ve sosyokültürel gelişimlerine olumlu yada olumsuz katkı sağlamaktadır.

Bu çalışmanın amacı Türkiye'de ve Almanya'da ikinci sınıftan yedinci sınıfa kadar kullanılan ana dil Türkçe ve Almanca ders kitaplarında toplumsal cinsiyet rolüne ne kadar değinildiğini ortaya koymaktır. Araştırma kapsamında şu sorulara cevap aranacaktır: Seçilen Türkçe ve Almanca ders kitaplarında toplumsal cinsiyet rollerine dair izler var midır? Almanca ve Türkçe ana dil ders kitaplarında roller nasıl ifade edilmiştir, aralarında nasıl farklar vardır gibi sorular yanıtlanmaya çalışılacaktır.

\section{Toplumsal Cinsiyet Rolleri}

Toplumsal cinsiyet, kadın ve erkeğe yüklenen sosyolojik bir anlamdır. Dökmen (2010) toplumun tanımladığ 1 ve bireylerin yerine getirmelerini beklediği cinsiyetle ilgili bir grup beklenti sonucu toplumsal cinsiyet rolleri ortaya çıtığını söylemektedir. Buna ek olarak toplumsal cinsiyet, toplum ve kültür tarafından yapılandırılmış biyolojik cinsiyetten bağımsız olarak gelişen cinsiyet rollerini, statü ve sorumlulukları ifade etmektedir (Yogev, 2006, s.8). Metin (2011)'e göre kimlikler üretilmekten ziyade miras olarak alınmaktadır. Anne karnındaki bebeğin cinsiyetinin kız yada erkek olduğu öğrenildiği andan itibaren o cinse atfedilen toplumsal cinsiyet rolleri devreye girer. Miras olarak alınan bu roller ebeveynlerden çocuklara aktarılarak sürdürülür. Erkek çocuk aslan oğlum 
diye yüceltilirken, kız çocuklar prenses kızım diye sevilir. Böylece çocuklar kendilerine atfedilen bu sıfatlara hem alışırlar hem de onları benimserler. Erkek çocuklar, kızların prenses olduğunu yani gizil düşünce olarak kırılgan, naif, hassas olduklarını, kız çocuklar ise erkeklerin güçlü, kararlı ve otorite olduğunu bilinçaltına kodlamış olur. Özaydınlık (2014), kişilikle ilgili olarak toplumsal cinsiyet rollerinde kadınların zayıf, pasif erkeklerin güçlü ve zeki bireyler olarak gösterildiğini söylemektedir.

“Toplumsal cinsiyet, kadınlar ile erkekler arasındaki farklılıkların toplumsal düzlemde kurulmuş yönlerine dikkat çekmektedir (Marshall, 1999, s.98). Kız ve erkek çocuklara bilinçli yada bilinçsizce atfedilen sıfatlar; aslında kendilerine dayatılan kalıp yargılarıdır. Çıtak (2008)'a göre her toplumda var olan ve kültüre göre belirlenen bu kalıp yargılar kadın ve erkeklerin kendilerini belirli ve beklentilere cevap verecek şekilde davranmalarına yol açarak bir baskı yaratır. Bu beklenti çok olağanmış gibi günlük hayatta insanların karşısına çıkar. Bireyler, çevreleriyle birlikte var olurlar. Kendilerine ilk örnek olan ailelerini model alırlar. Erken yaştan itibaren anne, baba ve etraflarındaki kişilerin tutum ve davranışlarını gözlemleyerek, cinsiyetlere biçilen rolleri fark etmeden kabullenirler. Esen (2013)'e göre, cinsiyet rollerinin nasıl kazanıldığına ilişkin yaklaşımlara göre çocuklar, ait oldukları cinsiyete yüklenen rolleri benimsemeyi ve bu rolleri içselleştirmeyi çok erken yaşlarda, ilk toplumsallaşma ortamı olan ailede, çeşitli yollarla öğrenirler. Eğitimi ailede başlayan bu cinsiyet rolleri, okullarda devam ettirilebilir yada eşitlikçi bir anlaysşla cinslerden herhangi birini yermeden veyahut yüceltmeden tarafsız şekilde yansıtabilir. Bu durum devletlerin eğitim politikalarıyla ilgili bir durumdur.

\section{Eğitimde Cinsiyet}

Okullar, eğitim ve öğretimin bilinçli olarak yapıldığı örgün kurumlardır. Topluma eğitimli bireyler yetiştirmek okulların temel amaçlarından biridir. Özaydınlık (2014) bireylerin toplumda etkin bir rol alması, toplumda uyum içinde yaşayabilmesinin temel hak ve özgürlüklerini bilmesi ile yakından ilişkili olduğunu ve bu haklardan biri olan eğitimin, diğer haklarını bilme ve kullanması açısından son derece önemli olduğunu vurgulamiştır. 
Kadının Statüsü Genel Merkezi (KSGM) 2012 raporuna göre modern toplumun, üretken ve kaliteli bir yaşamın ön koşulu olan eğitim, günümüz dünyasındaki hılı değişim ve gelişim sürecine uyum sağlama konusunda anahtar kavramdir. Bu nedenle bir toplumun bireylerine vereceği eğitimin niteliği, toplumun tüm kesimlerini içine alması açısından büyük bir önem taşımaktadır. Esen ve Bağlı (2002)'ya göre bireyin başarılı bir şekilde toplumsallaşması için okullar daha sistemli ve planlı bir çalışma yürütmektedir. Çünkü öğretimle birlikte eğitimin de merkezi olan okulun temel amaçları arasında çocukları toplumsallaştırmak, toplumda üretici bireyler olarak işlevde bulunmaları için gerekli bilgi ve becerilerle donatmak ve toplumun kültürel değerlerini yeni kuşaklara aktarmak yer alır. Eğitim hakkı insanın sahip olduğu en önemli haklardandır. Ancak eğitimin içeriğini iyi belirlemek gerekir. Zira eğitimin içeriği bireyleri güçlendirebileceği gibi güçsüz de kılabilir.

Çocukların okula ilk adım attığında karşılaştıkları ders materyallerden biri olan ders kitaplarının içeriği büyük önem taşımaktadır. Baştürk (2006)'e göre ders kitabı, çocuğun yaşadığı toplumla bütünleşmesini sağlayan, o toplumun inançlarını, kültürünü, yaşam biçimini, felsefesini, etkileşim biçimlerini, gelenek ve göreneklerini açılayan ve öğreten ilk kaynaktır. Bu bağlamda eğitim, kişiye birçok bilgiyi öğrenme, sosyal çevre ve meslek edinebilme fırsatı sağlamasının yanında hayata karşı farkındalık kazanma, kendini tanıma, topluma ve hayatı anlama gibi konularda bireye yardımcı olmaktadır. Bahsedilen bu kazanımların gerçekleşmesi için aracı kaynaklar vardır. Okul bu işlevleri çeşitli öğe ve materyallerle gerçekleştirir. (Kılıç ve Eyüp, 2011, s.131) okullarda hedeflenen eğitim çıktıları belirli planlamalarla çoğunlukla basılı materyal olan ders kitapları aracılığıyla yapılmaktadır. Örgün eğitim kurumlarında okutulan ders kitapları ve niteliği öğrencilerin toplumsal açıdan beklenen davranışları kazanmaları ve bekleneni gerçekleştirmeleri açısından önemlidir. Ne var ki ders kitaplarının istenene uygun olarak hazırlandığ 1 söylenenemektedir. Bu nedenle çocuklara sunulan ders materyallerinin onların ruhsal ve sosyolojik gelişmelerinin temelinde yer alan cinsiyet rollerinin hangi tutumla ele alındığının irdelenmesi eğitimin temeli olan istendik davranışların elde edilmesi bakımından anlam kazanmaktadır. Devletin denetiminden geçip çocuklara ulaşan bu materyallerin cinsiyet rolleri dikkate alınarak hazırlanması gerekmektedir. 
Ders kitaplarında, toplumsal cinsiyetin ve cinsiyet rollerinin nasıl yansıtıldığı, o toplumda nasıl bir gelecek inşa edilmek istendiğinin açık bir göstergesi olarak değerlendirilebilmektedir. Eğitim materyallerindeki metin, resim, fotoğraf kısacası her bir söz ve imge çocukların zihninde bir cinsiyet algısı oluşturur. Kadının ve erkeğin davranışlarının nasıl olduğunu yansıtan ve aslında nasıl olması gerektiğini göstermesi gereken bu materyaller bireylerin tüm yaşamlarını, öncelikle kendi cinsiyetlerine olan bakışlarını ve karşı cinsle olan iletişim ve ilişkilerini etkileyecek ve belirleyici rol oynayacaktır. Öğrencilerin en çok karşılaştığ1 araç ders kitabı olduğu için verilen örtük ya da açık mesajlar öğrencide bir düşünce oluşturmakta ve zamanla davranışa dönüşebilmektedir. Bu durumda her iki cinsinde eşit olarak sahip olması gereken eğitim haklarında haksızlıklar ortaya çıkmaktadır. Kısaca eğitim haklarının kullanılmasına yönelik toplumda çeşitli sorunlar yaşanabilmekte, çeşitli engellerle karşılaşılabilmektedir. Bu engellerden belki en önemlisi toplumsal cinsiyet eşitsizliği ve veya cinsiyetçi tutumlardır (Özaydınlık, 2014, s.96).

\section{Cinsiyet ve Sosyal Öğrenme}

Bireylerin cinsiyet rolünü nasıl kazandığına dair "sosyal öğrenme kuramı, sosyal bilişsel kuram ve toplumsal cinsiyet şeması kuramı" gibi farklı kuram ve bakış açıları ortaya çıkmıştır. Her üç kurama göre de çocuklar okula başladıklarında zaten cinsiyet temelli düşünce ve davranışlarla donanmışlardır. Fakat süreç henüz bitmemiştir. Cinsiyet rolü kimliği okul yaşamı sürecinde de gelişmeye devam edecektir. Okul, çocukları yalnızca genel bir biçimde toplumsallaştırmakla kalmaz, aynı zamanda toplumsal cinsiyet rollerinin ayrıştırılıp kodlanmasında da güçlü ve sınırlayıcı bir etkiye sahiptir (Esen, 2013).

Toplumsal cinsiyet konusunda yapılan çalışmalar bu kavramı sosyal öğrenme kuramı ile bağdaştırır. Sosyal öğrenme kuramı, temelinde bireylerin başkalarını gözlemleyerek öğrenmeyi gerçekleştirdiğini öne sürer. Buna göre çocukların cinsel kimlik rollerine ilişkin bilgileri ilk olarak ebeveynler, daha sonra yakın sosyal çevre ve hayatlarının devamında etkin olan kitle iletişim araçlarının ilettiği mesajlara dayanmaktadır. Eren (2015) gözlemleme ve taklit sürecinde erkek çocukların yalnızca babalarını ve kız çocukların yalnızca annelerini gözlemlemediğini vurgulamış 
ve çocukların gelişim sürecinde çocuğun kendi cinsinden olan öğretmenler, diğer yetişkinler, arkadaşlar, kardeşler, medyadaki kadın ve erkek temsilleri ile kitaplardaki karakterleri de gözlemlediklerini belirtmiştir.

Kimlik gelişimi henüz tamamlanmadığ i için okullarda kullanılan ders kitapları çocukların üzerinde hem olumlu hem de olumsuz etkiye sahiptir. Toplumda var olan geleneksel rolleri yansitmak ve bu rollerin sürdürülmelerini sağlamak yerine cinsiyetlerin eşit haklara sahip olduğunu gösteren, kimlik gelişimi henüz tamamlanmamış olan çocuklara geleneksel rolleri dayatmayan ders materyallerinin hazırlanması gerekmektedir. Çünkü Dökmen'e göre sosyalleşme sürecinde kız ve erkek çocuklar çeşitli nesneleri, etkinlikleri, oyunları, meslekleri ve hatta kişilik özelliklerini onlar için uygun ya da uygunsuz olarak ayırt etmeyi öğrenmektedirler (Dökmen, 2010, s.45).

Ders kitaplarındaki her görsel ve yazılı metin öğrenciye bir mesajdır. Her bir metin ve o metindeki karakterlerin neler söylediği, neler yaptığı, kız ve erkek çocuklarının bilinçaltına kaydedilmektedir. Kılıç ve Eyüp (2011) öğrencilerin, metinlerde yazarların onlara sunduğu dünya ile gerçek hayat arasındaki benzerlikleri ve farklılıkları görerek pek çok şey öğrendiklerini belirtmiştir. Öğrencilerin ufkunu açması beklenen kitaplar bakış açılarını belli bir davranış kalıbına sokmamalıdır. Öğrenciye özgür düşünce ortamı sunmalı, hatta toplumda var olan cinsiyet eşitsizliklerinin yanlış olduğunu gösterebilmeli ve bu konu üzerinde söz söyleyebilecek eleştirel bakış açısını da kazandırmalıdır.

\section{Yöntem}

$\mathrm{Bu}$ çalışmada nitel araştırma yöntemlerinden olan içerik analizi kullanılmıştır . İçerik analizi belirli kurallara dayalı kodlamalarla bir metnin bazı sözcüklerinin daha küçük içerik kategorileri ile özetlendiği sistematik, yinelenebilir bir teknik olarak tanımlanır (Büyüköztürk, 2012, s.34). Kitaplarda kullanılan metinler ve görseller incelenmiştir. İçerik analizinin metinler, resimler gibi malzemelerle çalıştığını vurgulamıştır (Gökçe, 2006, s.18). İçerik analizinde incelemeler, belli kodlamalara göre yapılmaktadır. Kodlar belirlenirken uzman görüşü alınmıştır. Belirlenen kodlar; aile içi ve dışı roller, meslek roller ve cinsiyet rolleridir. Türkiye'de MEB'in 2.3.4 ve 5. Sınıf türkçe ders kitapları ile almanca Niko Sprachbuch 
2-3-4 ve 5. Sınıf için Deutsch kombi plus kitabı random yöntemiyle seçilmiştir.

\section{Bulgular}

Bu bölümde, incelenmiş olan 2.3.4. ve 5. Sınıf Türkçe ve Almanca ana dil ders kitaplarından içerik analizi yöntemiyle elde edilen veriler tablo halinde gösterilmiştir. Ders kitapları dört farklı ana başlık altında incelenmiştir. Bu başlıklar; aile içi ve dışı roller, meslek rolleri, ev içi roller ve cinsiyet rolleri olarak belirlenmiştir. Tablolarda " $\mathrm{T}$ " ile belirtilen Türkçe kitaplarına " $\mathrm{A}$ " ile belirtilenler ise Almanca kitaplarına işaret etmektedir. Ayrıca kadın ve kız çocukları için "K" erkek ve erkek çocukları için ise " $E$ " kısaltması kullanılmıştır.

Tablo 1. 2. Sınıf kitaplarında aile içi ve dışı roller

\begin{tabular}{lllll}
\hline \multicolumn{1}{c}{ Aile içi } & & \multicolumn{2}{c}{ Aile dışı } & \\
\hline & $\mathrm{K}$ & $\mathrm{E}$ & $\mathrm{K}$ & $\mathrm{E}$ \\
\hline $\mathrm{T}$ & Odayı & Haftasonu takım & - & - \\
& toplayan anne & klyafetiyle kahvaltı & & \\
& Yemek yapmak & yapan baba & & - \\
\hline $\mathrm{A}$ & - & - & - & \\
\hline
\end{tabular}

Tablo 1'de Türkçe 2. Sınıf ders kitaplarında odayı toplayan bir anne resmedilmiştir. Ev işlerinin kadına ait olduğu mesajı açıkça yansıtılmıştır. "Kız çocuklarına ve kadınlara belirli toplumsal rollerin yakıştırılması ve bunun sürekli pekiştirilmesi anlamına gelecek ifade ve uygulamalar ders kitaplarından çıkartılmalıdır" ibaresi ders kitaplarında insan hakları II projesi 2009 raporunda yer almaktadır. Bu durum "ders kitaplarında insan hakları projesi 2009" raporuna uymamaktadır ve kitapların hazırlanırken bu raporun verilerinin dikkate alınmadığını görülmektedir. Erkeğin yada erkek çocuğun evdeki görev ve sorumluluklarına dair herhangi bir mesaj yoktur. Evin reisi sifatına uygun olarak haftasonu kahvaltı masasında takım kıyafetiyle oturan bir baba resmedilmiştir. Almanca 2. Sınıf ders kitabında ise aile içi ve dışı görevler konusunda herhangi bir mesaj yoktur. 
Tablo 2. 2. Sinif kitaplarnda meslek rolleri

\begin{tabular}{lll}
\hline \multicolumn{2}{l}{ Meslek Rolleri } & \\
\hline & K & E \\
$\mathrm{T}$ & 3 öğretmen & Asker \\
$\mathrm{A}$ & 1 öğretmen & - \\
\hline
\end{tabular}

Tablo 2'de Türkçe ders kitaplarında öğretmenlik mesleği üç kadına ve askerlik mesleği erkeğe yakıştırılmıştır. Almanca ders kitaplarında da öğretmenlik yapan bir kadın gösterilmiştir. Bu kitapta erkek herhangi bir meslek grubu içinde tanımlanmamıştır.

Tablo 2'e göre evde yemek yapma sorumluluğu kadına verilmiştir. Ev içi rollerde yine kadın ön plandadır denilemez, ev içi işler sadece kadınındır mesajı vardır. Almanca ders kitabında ise bu konuda bir mesaj bulunamamıştır.

Tablo3. 2. Sinıf kitaplarnda cinsiyet rolleri

\begin{tabular}{lll}
\hline \multicolumn{1}{l}{ Cinsiyet rolleri } & E \\
\hline $\mathrm{K}$ & Bebeği ile oynamak & $\begin{array}{l}\text { Basketbol oynamak, ata binmek, parkta } \\
\text { oynamak, bisiklet sürmek, kömürü bulan } \\
\text { erkek örneği, müze gezmek, kitap okumak }\end{array}$ \\
\hline $\mathrm{A}$ & $\begin{array}{l}\text { Çiçek bakmak, yemek pişirmek, } \\
\text { alışveriş yapmak, kitap okumak }\end{array}$ & $\begin{array}{l}\text { Arabayla oynamak, bulaşıları kurulamak, } \\
\text { çimleri biçmek, odayı toplamak }\end{array}$ \\
\hline
\end{tabular}

2. sınıf ders kitaplarında kızlar bebeğiyle oynayarak tek bir etkinlik içerisinde gösterilirken, erkekler ise basketbol oynamak, ata binmek, parkta oynamak, bisiklet sürmek, müze gezmek ve kitap okumak gibi 6 farklı etkinlik içerisinde gösterilmiştir. Bu etkinlikler ağırlıklı olarak dışarıda yapılan kültürel faaliyetlerdir. Almanca ders kitabında ise kız çocuklar ve kadınlar çiçek bakmak, yemek pişirmek, alışveriş yapmak ve kitap okumak gibi dört farklı etkinlik içerisinde gösterilmiştir. Erkekler ve erkek çocuklar ise arabayla oynarken, bulaşıkları kurularken, çimleri biçerken ve odayı toplarken resmedilmiştir. Erkekler ile ilgili bu etkinlikler bu görevlerin kadınlara ya da kız çocuklara ait olmadığını göstermektedir.

Tablo 4'de Türkçe ders kitaplarında para biriktirmek ve çiçek bakmak kadınların yaptığı bir davranış olarak gösterilmiştir. Ev dışı rol olarak annenin de çalışabileceği normu öğrencilere aktarılmıştır. Almanca ders kitaplarında ise bu konuyla ilgili herhangi bir duruma yer verilmemiştir. 
Tablo 4. 3. Sınıf kitaplarda aile içi ve aile dışı roller

\begin{tabular}{lllll}
\hline & Aile içi & E & Aile dişı & \\
\hline $\mathrm{T}$ & Para biriktirmek, çiçek & Saksı almak & K & E \\
& $\begin{array}{l}\text { bakmak Mutfakta kek } \\
\text { pişirmek, kapıyı açmak }\end{array}$ & $\begin{array}{l}\text { Bir } \\
\text { işte çalışmak }\end{array}$ & $\begin{array}{l}\text { Bir } \\
\text { işte çalışmak }\end{array}$ \\
\hline $\mathrm{A}$ & - & $\begin{array}{l}\text { Krep yapmak, anneye } \\
\text { bulaşıkta kurulama } \\
\text { yardımı yapmak }\end{array}$ & - & - \\
& & & \\
\hline
\end{tabular}

Tablo 5. 3. Sint kitaplarnda meslek rolleri

\begin{tabular}{lll}
\hline \multicolumn{2}{l}{ Meslek Rolleri } & \\
\hline & K & E \\
\hline $\mathrm{T}$ & Öğretmen & Fırıncı, çiftçi, fabrikada çalışan işçiler \\
\hline $\mathrm{A}$ & İki öğretmen, terzi, eczacı & - \\
\hline
\end{tabular}

3. sınıf Türkçe ders kitaplarında öğretmenlik mesleği kadına verilirken; erkekler fırıncl, çiftçi, fabrikada çalışan işçiler olarak gösterilmiştir. Almanca kitaplarda ise öğretmenlik, terzilik ve eczacılık kadınlara yakıştırılmıştır.

3. sınıf Türkçe ders kitaplarında kadınlara ve kız çocuklarına mutfakta kek pişirmek ve eve gelene kapıyı açma görevi verilmiştir. Bu durum aile içinde muhabbeti, sevgiyi arttıran bir davranış da olsa kitabın geneline bakıldığında evin ve çocukların tüm sorumluluğunun anneye yani evin kadınına ait olarak gösterilmesi cinsiyet ayrımına yol açmaktadır. Erkeğe ise ev için gerekli olan saksıyı dışarıdan alma görevi verilmiştir.

Buna karşılık, Almanca ders kitaplarında kadınlara krep yapmak, kız çocuklara anneye mutfakta yardım etme görevi verilmiştir. Almanca 3. Sınıf ders kitaplarında erkeklere ev içi rollerde herhangi bir şey yansıtılmamıştır.

Tablo 6. 3. Sinf ders kitaplarnda cinsiyet rolleri

\begin{tabular}{lll}
\hline \multicolumn{2}{l}{ Cinsiyet rolleri } & \\
\hline & K & E \\
\hline $\mathrm{T}$ & $\begin{array}{l}\text { Masalda evlilik ile ödüllendirilenmek, } \\
\text { prensin öperek uyandırdığı prenses }\end{array}$ & - \\
\hline $\mathrm{A}$ & - & Kız öğrenciye şiddet uygulamak \\
\hline
\end{tabular}

3. sınıf Türkçe ders kitabında geçen bir masalda kadınlar evlilik ile ödüllendirilmektedir. Almanca ders kitaplarında ise erkek öğretmen kaba 
kuvvet uygulayan bir rolde yansıtılmıştır. Bu görselde öğretmen bir kız öğrenciyi azarlayan ve ona fiziki şiddet uygulayan biri olarak gösterilmiştir. Böylelikle erkeğin kaba kuvvete ve şiddete meyilli olduğu vurgulanmak istenmiştir.

Tablo 7. 4. Sınıf ders kitaplarında aile içi ve dışı roller

\begin{tabular}{|c|c|c|c|c|}
\hline & \multicolumn{2}{|r|}{ Aile içi } & \multicolumn{2}{|c|}{ Aile dışı } \\
\hline & $\mathrm{K}$ & $\mathrm{E}$ & $\mathrm{K}$ & $\mathbf{E}$ \\
\hline $\mathrm{T}$ & $\begin{array}{l}\text { Pazar alışverişi, } \\
\text { kızıyla gezmek } \\
\text { Ev süpürmek, } \\
\text { patatesleri soymak, } \\
\text { kıyma çıarmak, } \\
\text { çocuğa ödevlerinde } \\
\text { yardım etmek }\end{array}$ & $\begin{array}{l}\text { Oğluyla gezmek, kuzuları gü- } \\
\text { tmek, tarlaya yemek götürmek, } \\
\text { tarla sulamak, "evli } \\
\text { ve çocuklu olarak gezilmez" } \\
\text { mesajı verilmiştir } \\
\text { "ortalığıdağıtma yeter". Patates } \\
\text { soymak(erkek çocuk ablasına } \\
\text { yardım etti) Ablam kendini } \\
\text { annem sanmaya başladı, } \\
\text { harçlık ver vermek }\end{array}$ & - & -- \\
\hline A & $\begin{array}{l}\text { Çocuğuna } \\
\text { kapıyı açmak } \\
\text { Bulaşık } \\
\text { yıkamak, } \\
\text { yemek pişirmek }\end{array}$ & $\begin{array}{l}\text { Hediye isteyen çocuğuna, "an- } \\
\text { nenle konuşmalıyım" demek, ba- } \\
\text { bayla bisiklet tamiri yapmak, Bu- } \\
\text { laşıkları kurulamak }\end{array}$ & & - \\
\hline
\end{tabular}

Tablo 7'de Türkçe ders kitaplarında pazar alışverişine çıan bir kadın gösterilmiştir. Anne kızıyla dışarıda baba da oğluyla gezmektedir. Erkek çocuk kuzuları güden, tarlaya yemek götürmektedir. Tarlayısulayan erkek ise evli ve çocuklu bir bireydir. Almanca ders kitabında da evde olup çocuğuna kapıyı açmak, annenin yaptığı bir davranış olarak gösterilmiştir. Bu davranışa aynı seviyedeki Türkçe ders kitabında da rastlanmıştır. Kendisinden hediye isteyen çocuğuna bu konuyu eşiyle konuşması gerektiğini bildiren baba ile demokratik bir aile tablosu çizilmiştir. Evde kadın veya erkeğin ebeveyn olarak her ikisininde söz sahibi olduğu mesajı verilmek istenmiştir.

Tablo 8. 4. Sinıf ders kitaplarinda meslek rolleri

\begin{tabular}{lll}
\hline \multicolumn{1}{l}{ Meslek Rolleri } & \\
\hline & K & E \\
\hline $\mathrm{T}$ & - & $\begin{array}{l}\text { Boyacılık, pazarcılık, ayakkabıcılık, } \\
\text { tarlada çalışmak, terzi. }\end{array}$ \\
\hline $\mathrm{A}$ & $\begin{array}{l}\text { öğretmen, polis, } \\
\text { pilot, terzi, yazar. }\end{array}$ & $\begin{array}{l}\text { Çiftçi, profesör, itfaiyeci, araştırmacı, öğretmen, } \\
\text { bilgisayar programcısı, doktor. }\end{array}$ \\
\hline
\end{tabular}


4. sınıf Türkçe ders kitabında kadın herhangi bir meslek grubunda çalışma durumunda gösterilmemiştir. Erkekler ise boyacılık, ayakkabıcılık, tarlada çalışmak ve terzilik gibi mesleklerle ifade edilmiştir. Almanca 4. Sınıf ders kitabına bakıldığında ise, kadınlar öğretmen, polis, pilot, terzi ve yazar gibi mesleklerle ifade edilmiştir. Hatta kitabın bu bölümünde kız ve erkek çocuklara hangi meslekleri yapmak istedikleri sorulmuştur. Erkek öğrencilere profesör, itfaiyeci, araştırmacı, öğretmen, bilgisayar programcısı gibi farklı meslekler yakıştırılmıştır.

4. sınıf Türkçe ders kitabında kadınlara ev süpürmek, patatesleri soymak, yemek yapmak için dolaptan kıyma çıkarmak ve çocuğun ödevlerine yardım etmek gibi görevler yüklenmiştir. Erkek çocuğa ortalığı dağıtmamasının yeterli olduğunu mesajı verilmiştir. Çocuğuna harçlık verme görevi de erkeğe atfedilmiştir. Almanca kitaba baktığımızda ise kadına bulaşık yıkama, yemek pişirme gibi geleneksel görevler verilmiştir. Buna karşın bulaşıkları kurulayarak kadına yardım etme görevi erkeğe verilmiştir. Burada mutfakta asli görevin kadının olduğu ve erkeğin sadece yan sorumluluklar alacağı mesajı açıkça görülmektedir.

Tablo 9. 4. Sinı kitaplarında cinsiyet rolleri

\begin{tabular}{lll}
\hline \multicolumn{2}{l}{ Cinsiyet rolleri } & E \\
\hline $\mathrm{T}$ & $\begin{array}{l}\text { Bebekle oynamak, etekli dört kız ve anne, } \\
\text { örgü ören kadın, kayınvalideye “kay- } \\
\text { nanam” ifadesi kullanılmıştır. }\end{array}$ & $\begin{array}{l}\text { Futbol oynamak, basketbol } \\
\text { oynamak, olimpiyat koşmak }\end{array}$ \\
\hline $\mathrm{A}$ & $\begin{array}{l}\text { İyi kalpli, şişman, keyfine düşkün, kendini } \\
\text { erkeğe beğendirme çabası (ob sie Lukas ge- } \\
\text { fallen würde), bebeğinin saçını taramak }\end{array}$ & $\begin{array}{l}\text { Kızı beğenmesi gereken (lukas } \\
\text { schaute sie von oben bis unten } \\
\text { an), evli Zeus bir kızı kandırıyor, } \\
\text { kitap okumak, çekiçle oynamak }\end{array}$ \\
\hline
\end{tabular}

Tablo 9'da Türkçe ders kitaplarda kadınlara ve kız çocuklarına bebekle oynamak, örgü örmek gibi davranış kalıpları atfedilmiştir. Kaynana kelimesi Türk kültürünü yansıtmakta olup, eşin annesine takılmış bir kısaltmadır. Bu durumda kadın hem cinsi olan diğer bir kadını yermektedir. Erkekler ise futbol oynamak, basketbol oynamak, olimpiyatlara katılmak gibi sosyal ve kültürel etkinlikler içinde yer almıştır. Almanca kitaba bakıldığında ise kadın iyi kalpli, kilolu ve keyfine düşkün olarak 
tanıtılmıştır. Ayrıca erkeğe kendini beğendirme düşüncesi olan bir kız betimlenmiştir. Bu resimde erkek çocuk kız çocuğu baştan aşağı süzmektedir. Ayrıca mitolojiden önemli bir yeri olan Zeus'a değinilerek erkek figürünün bir kızı kandırdığından bahsedilmiştir. Böylece kadınlar çabuk aldatılabilen imajı çizilmiştir.

Tablo 10'a göre 5. Sınıf Türkçe ders kitaplarında kadının ve erkeğin aile içi ve dışı rollerine dair bir mesaj verilmemiştir. Almanca ders kitaplarında ise anne olan kadına çocuğu uyandırıp, okula gönderme görevi verilmiştir.

Tablo 10. 5. Sınıf ders kitaplarında aile içi ve dışı roller

\begin{tabular}{lllll}
\hline & \multicolumn{2}{c}{ Aile içi } & & Aile dışı \\
\hline $\mathrm{K}$ & $\mathbf{E}$ & $\mathbf{K}$ & $\mathbf{E}$ \\
\hline $\mathrm{T}$ & Yemek yapmak & $\begin{array}{l}\text { Kurabiye yapmak, çay } \\
\text { demlemek }\end{array}$ & - & - \\
\hline $\mathrm{A}$ & $\begin{array}{l}\text { Çocuğunu uyandırmaya } \\
\text { giden anne, } \\
\text { Yemeğe çağırmak, } \\
\text { çarşaf silkelemek }\end{array}$ & - & - & - \\
& & & \\
\hline
\end{tabular}

Tablo 11. 5. Sinif ders kitaplarnda meslek rolleri

\begin{tabular}{ccl}
\hline \multicolumn{3}{l}{ Meslek Rolleri } \\
\hline & K & E \\
\hline $\mathrm{T}$ & - & - \\
\hline $\mathrm{A}$ & Kaleci, öğretmen, aşçı, yazar & öğretmen, Profesör, aşçı, terzi, yazar \\
\hline
\end{tabular}

5. sınıf Türkçe ders kitaplarında kadın ve erkeğin meslek rollerine yönelik bir betimlemede bulunulmamıştır. Buna karşın Almanca ders kitabında ise kadının kaleci, öğretmen, aşçı ve yazar olabileceği, erkeğin ise öğretmen, profesör, aşçı, terzi ve yazar olabileceği belirtilmiştir.

Tablo 11'de Türkçe ders kitaplarında kadının evde yemek yapacağ1, erkeğinde kurabiye yapıp çay demleyebileceği mesajı verilmiştir. Türkçe ders kitaplarında erkeğe mutfakta yemek yapma rolü verilmemiştir. Almanca ders kitabında ise anne rolündeki bir kadın diğerlerini yemeğe çağırmaktadır. Masallardan bahsedilen kısımda ise bir kalenin içinde saçlarını uzatarak erkekten yardım bekleyen Rapunzel çarşaf silkelemektedir. Masal için yapılan görsellerde kadın her durumda evle ilgili işlerle anlatılmıştır. Erkeğe herhangi bir ev içi rol verilmemiştir. 
5. sınıf Türkçe ders kitaplarında cinsiyet rollerine bakıldığında kaynana sözünün geçtiği görülmektedir. Toplumda genellikle olumsuz anlamda kullanılan bu tanımlamanın ders kitabında kullanıldığı görülmektedir. Diğer bir nokta ise kayınvalide olan kadının oğlunun yanına gelini mesleği dolayısıyla yakıştırmış olmasıdır. Buna ilaveten bir kadın güzelliği ile betimlenmiş, erkekler içinse ağlamamaları gerektiği vurgulanmıştır. Türk kültüründe erkeklerin duygularını gizlemeleri gerektiği yaygın kanıdır. Çocukların kötü davranışlarının anneye çektiği görüşü de toplumda yaygın olarak kullanılmaktadır. Bu tür söylemler anneyi aşağılama amaçlıdır. Bilimle uğraşmak gibi kıymetli bir alan ise erkeklere özgü bir uğraş olarak gösterilmiştir

Tablo 12. 5. Sinıf ders kitaplarında cinsiyet rolleri

\begin{tabular}{lll}
\hline \multicolumn{2}{l}{ Cinsiyet rolleri } & E \\
\hline $\mathrm{T}$ & $\begin{array}{l}\text { Gelin kaynana kelimeleri (kaynananın } \\
\text { sözüne kulak ver) oğlumun maaşı iyi } \\
\text { gelin de mimar, üretimde bir kadın, } \\
\text { güzel kız }\end{array}$ & $\begin{array}{l}\text { Erkek ağlamaz, Çocuklar sana çekti. } \\
\text { Kavga eder }\end{array}$ \\
& $\begin{array}{l}\text { Çok konuşan Ayşe ve Aylin projede } \\
\text { üretim yapıyor. }\end{array}$ & $\begin{array}{l}\text { Az konuşan, Alaycl, futbol oynayan, } \\
\text { projede çalışan }\end{array}$ \\
\hline $\mathrm{A}$ &
\end{tabular}

Almanca ders kitaplarında ise kadınların çok konuştuğu yönünde bir aşağılama kullanılmıştır. Buna karşın iki kız çocuğun bir projenin içinde yer alarak üretime katılıyor mesajı kız çocukları lehine önemli bir işarettir. Erkekler kızlara karşın az konuşan, alay eden ve futbol oynayan bireyler olarak yansitılmıştır.

\section{Tartışma}

Bu çalışmanın amacı, henüz eğitim öğretim yolunun başında olup hayata olan bakış açıları yeni şekillenmekte olan bireylere, ders kitapları aracılığıyla belli rollerin benimsetilmeye çalışılıp çalışılmadığını ortaya koymaktır. Eğitim ve öğretimin en temel materyallerinden birisi olan ders kitapları bu anlamda çok büyük bir önem kazanmaktadır. Her ne kadar belli davranışlar aile ve çevrede öğrenilse de, okulun ve dolayısıyla eğitime araç olan ders kitaplarının bireyin sosyal, bilişsel, duygusal gelişimlerine katkısı yadsınamaz. Çocuk kitaplarla büyür, onlar sayesinde 
kendisini, çevresini anlamaya başlar. Dünyayı tanır, kendisini keşfeder ve kimliğini oluşturur. "Aileler ve çevre erkek çocuklara kız gibi ağlama diyerek, kız çocuklara hanım hanımcık ol diyerek; sınır koymaktadır ve çocuklar çevrelerini bu şekilde algılamaya başlamaktadır" (Kalan,2010, s.78). Bu durumun çocuğun karakterinde yer etmemesi için bireylerin eşit olduğu görüşü onlara okullarda kazandırılması gereken temel bir düşüncedir. Ders kitaplarında kendine örnek alabileceği, kendisiyle özdeşleştirebileceği kadın karakterler göremeyen hatta kendi hemcinslerini erkeklere oranla çok daha az şekilde tasvir edilmiş olarak gören kız çocukları erkekler karşısında eşit olmadıkları sanısına kapılacaklardır. Bu durum henüz ilköğretim seviyesinde olan bireylerin zihninde dezavantajlı bir grup oldukları algisını yaratacaktır.
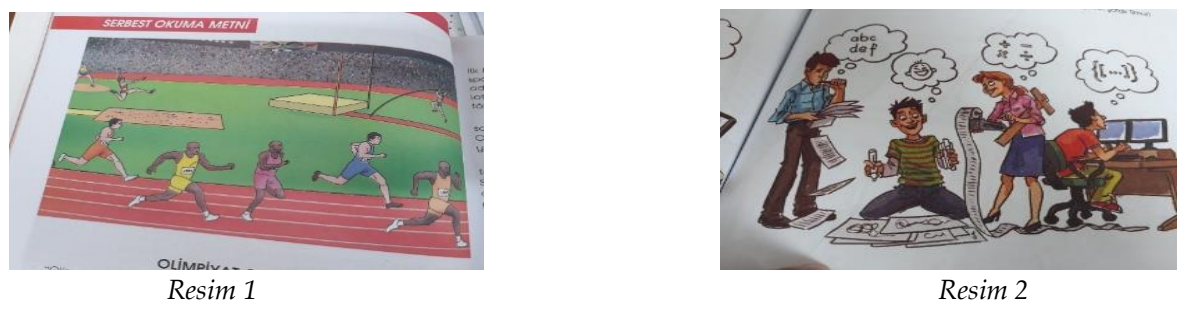

Resim 1. 2. 3. ve 4.'te Türkçe ders kitaplarından bazı resimler görülmektedir. Tablo 1'de spor etkinliklerine katılan yedi kişiden sadece biri kadındır ve o da arka plandadır. Tablo 2 de ise çalışma yapan bir grup içerisinde dört kişiden yalnızca birisi kadındır. Öğrencilere verilen bu gizil mesajlarla toplumda var olan eşitsizliğin alt yapısı oluşturulmaktadır. Fakat almanca ders kitaplarında bu durum farklıdır ve hatta kız çocuklarına resimlerde daha fazla yer verildiği görülmektedir. Bu iki ayrı kitapla yetişen iki farklı bireyin aynı eşitlik anlayışına sahip olması da beklenemez. Basmakalıp yargıların etkisi altında kalan birey özgür seçimler yapamaz ve kendini rahat ifade edemez. Bu da bireyin kişisel başarısı ve hayat tatminini olumsuz yönde etkileyecektir. 


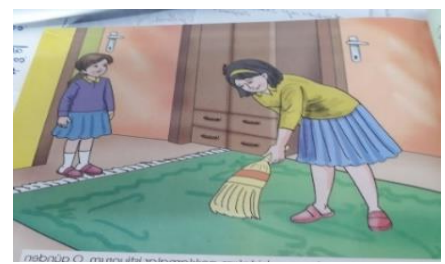

Resim 3

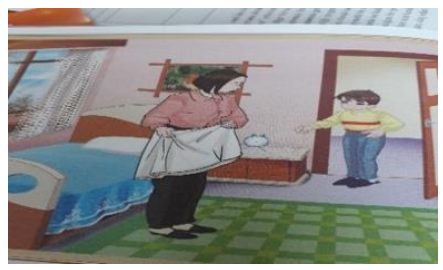

Resim 4

Dağabakan 1990'daki Hayat Bilgisi kitabından şu çıkarımlarda bulunmuştur: "kadın ailenin temelidir. Anneler çocuklarının beslenmesi, eğitimi, sağglı̆̆ gibi hususlarla yakından ilgilidir. Evin temizliği, yemeğin pişirilmesi, çamaşırların yıkanması gibi işler anne tarafından yapılır. Kadın aile hayatın düzenler". Bu ders kitabının hazırlanmasının üzerinden yirmi yedi yıl geçmiştir. Aile ilişkilerine önemli katkılar sağlayan ve aile bağlarını kuvvetlendiren bu tespitler yanlış olmamakla birlikte; yıllar içinde kadının çalışma hayatındak yeri ve rolü değiştiği için görev dağılımlarının yenilenmesi gerekmektedir. Değişmeyen rollerdeki bu durum ev içi rollerdeki kültürel bakış açısının değişmediğinin bir kanıtı niteliğindedir. İş hayatındaki dengeler büyük oranda değişmiş ve fakat evdeki işler kadının görevi olarak yerini korumuştur. Günümüzde eşlerin birçoğu aktif çalışma hayatında yerini almış olmasına rağmen evdeki tüm sorumlulukların 1990daki ders kitabında olduğu gibi aynen devam ettirildiği görülmektedir. Resim üç ve dörtte kadının yeri sadece evidir mesajı vardır. Bu mesaj bir anlamda kadın ev işlerini yapmalı, bilim, sanat ve kültürel faaliyetlerde rol almamalı yada alamaz olarak da yorumlanabilir.

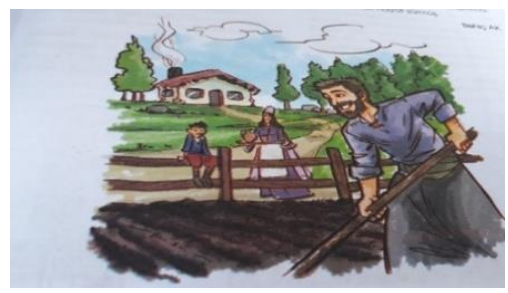

Resim 5

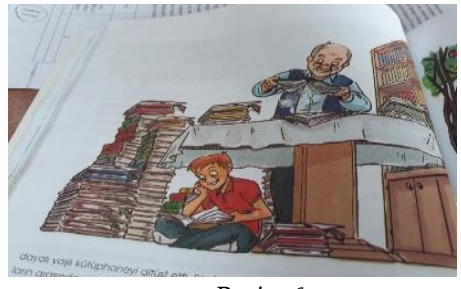

Resim 6

Bunun yanı sıra çalışma hayatında var olan kadınlar, kitaplarda sadece birkaç meslekle ve dar alanda tanımlanmış olup kız öğrencilerin kendilerine örnek alabileceği başarılı, özgüven sahibi örnekler bulunmamak- 
tadır. Bununla birlikte erkek öğrencilere verilen mesaj çok düşündürücüdür: kadın belli mesleklere sahip olabilir fakat tercihen evde iş yapmalı ve çocuklarına bakmalıdır. Başarı, azim ve girişimcilik gerektiren işleri erkekler yapmalıdır. Küçük yaşlardan itibaren bu mesajlarla yoğrulan erkek çocuklardan gelecekte kadınlara saygı duymasını beklemek, kadınların kendileriyle aynı haklara sahip olduğunu anlatmak kolay olmayacaktır. Çünkü onlara okullarda yıllarca kadının ve erkeğin hayattaki görevleri belirtilmiştir. Erkek çalışacak, kadın ise onun hayatını kolaylaştırıcı bir rolde yer alacak. Kadına evdeki temizlik işleri, düzen tertip ve yemek yapmak gibi rolleri üstleneceği bilinçaltına işlenmiştir. Bazı kadınlar evde annelerinin veya eşlerinin ev işlerini kendileriyle paylaşma taleplerini yadırgayacak ve reddedeceklerdir. Bunlara örnek olarak Resim 5 'de tarlada çalışan evin reisi ile ona yemek getiren kadın ve çocuğu görülmektedir. Burada bir iş bölümü yapılmış gibi görünse de kadını getir-götür işi yapmaktan yani arka planda kalan kişi olmaktan kurtaramamıştır. Resim 6'da ise ders kitaplarında okuyan, üreten bireylerin erkekler olduğuna dair çizilen resimlerden sadece birisidir. Ayrıca ayrımcılık yapılmadan hazırlanan kitaplarla eğitilen çocuklar, ilerde karşı cinse ayrımc davranmayacağı için oluşan yeni nesiller daha sağlıklı ve kadına karşı önyargısız olacaktır. Böylelikle kadını değersizleştirmeyecek hatta hakkı olan değeri de kendisinden esirgemeyecektir. Devlet kurumları tarafından hazırlanan ders kitapları kadın yada erkeği avantajlı yada dezavantajlı olarak yansıtmadan onlara sadece birer birey oldukları gözüyle bakmaları çok daha doğru olacaktır.

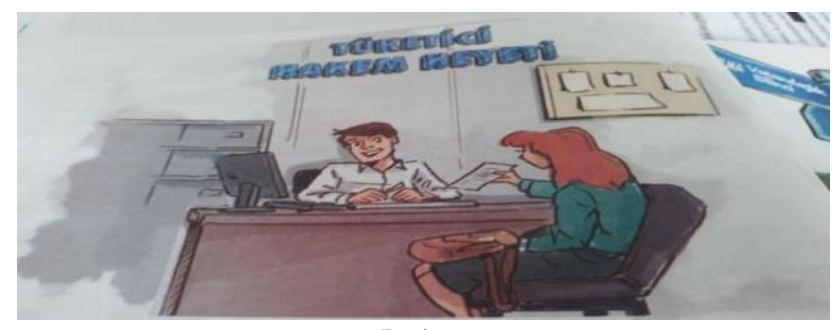

$\operatorname{Resim} 7$

Resim 7'de ise otorite rolünde olan bir erkek görülmektedir. Kadın ise erkekten bir ricada bulunmaktadır. Evet, kadın bir sorun sebebiyle bir kuruma başvurulabilir ve sorumlu yetkili kişide erkek olabilir. Bu doğaldır. 
Fakat ders kitaplarının içeriğinin büyük çoğunluğunda erkeğin öne çıkarılması ve kadının geri planda gösterilmesi doğru değildir.

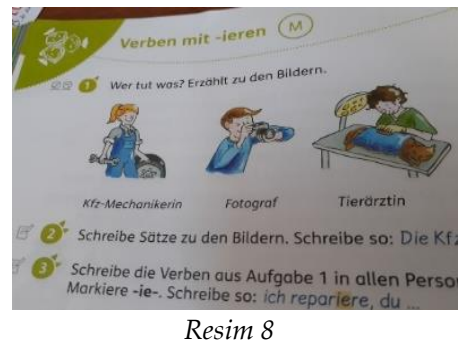

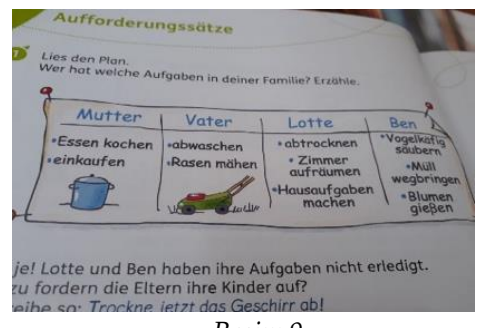

Resim 9

Resim 8'de almanca ders kitabında erkeklere uygun görülen meslekleri bir kız çocuğunun, bir kadının da yapabileceği gösterilmiştir. Tablo 9'da ise evde görev paylaşım listesi görülmektedir. Bu tabloda ev işlerine evin erkeğinin de erkek çocuğuna yardım etmesi gerektiği gösterilmiştir.

"Ders kitaplarında insan hakları projesi" (2009) raporuna göre; kız çocuklarına ve kadınlara belirli toplumsal rollerin yakıştırılması ve bunun sürekli pekiştirilmesi anlamına gelecek ifade ve uygulamaların ders kitaplarından çıkartılması gerektiği ifade edilmiştir. Bu raporda her ne kadar yapıcı öneriler bulunsada bunların uygulanmadığı görülmektedir.

Bu durum ders kitaplarını hazırlayan kişilerin bireysel bakış açılarıyla çok yakından ilgilidir. Ders kitabı hazırlamanın bir uzmanlık alanı olduğunu belirten raporda Eğitim Fakültelerinde ders kitaplarını incelemeye yönelik bir dersin olması gerektiği vurgulanmıştır. Bu doğrultuda böyle bir ders yapılsa bile cinsiyet incelemesini konu alan bir başlık yoktur. Yüksek öğretim kurumunun lisans ders içeriklerine baktığımızda ders kitabı inceleme dersi açıklamalarında insan hakları eşitliğine uygunluk ibaresi ya da bunu ima eden bir cümleye rastlanmamaktadır.

\section{Sonuç}

Bu çalışmada Türkiye'de ana dil derslerinde okutulan 2. 3. 4. ve 5. Sınıf Türkçe ders kitaplarıyla Almanya'da okutulan 2. 3. 4. ve 5. Sınıf ders kitapları toplumsal cinsiyet açısından incelenmiştir. Her iki toplumda da var olan benzerlikler ve farklılıklara dikkat çekilmiştir. Toplumsal cinsiyet 
rolleri kitaplarda; aile içi ve dışı roller, meslek rolleri, ve cinsiyet rolleri olarak dört ana başlık altında sınıflandırılmıştır.

Yapılan kitap incelemelerinde yemek yapmak, ev işleriyle uğraşmak her iki toplumda da kadının görevi olarak gösterilmiştir. Bu durum Türkçe kitaplarında daha yoğun, Almanca ders kitaplarında ise daha az ifade edilmiştir. Almanca ders kitaplarında erkeğin ve erkek çocukların da ev işlerinde sorumluluk aldığ 1 gösterilmiştir. Almanca ders kitaplarında bulunan fotoğraflarda kız çocuklar ve kadınlar erkeklerden daha fazla resmedilmiştir. Bu tür bir kitabı okuyan kız öğrencilerde bu yaklaşım olumlu tepkilere dönüşecektir. Kızlar bu kitaplarda gördükleri kimselerle kendilerini özdeşleştireceklerdir. Kendilerine benimsetilen roller sayesinde toplumda her zaman kendilerine bir yer edineceklerdir. Almanca ders kitabında öğrencilere hayallerindeki meslekler sorulmuş ve öğrenciler birçok meslek grubuna değinmişlerdir. Bu durum, Almanca ders kitaplarını hazırlayan uzmanların kız öğrencilerin yetiştirilirken erkek öğrencilerden ayrı tutulmadığına en önemli kanıtıdır.

Bireyler, hayatları boyunca bir çok seçim yapma eğiliminde ve mecburiyetindedirler. Edinecekleri meslek, çalışacakları yer yada yaşadıkları ev ortamında bazı işlerle uğraşırken sevdikleri ve mutlu olabilecekleri şeyleri seçmeye gayret ederler. Bu yüzden seçimleri cinsiyet ile sınırlamamak gerekmektedir. Kadına biçilen aşçılık rolünün aksine bir çok erkek severek yemek yapmaktadır ve hatta bir çok ünlü aşçı erkektir. Bununla birlikte her iki dildeki ders ktabında da öğretmenlik mesleği ağırlıklı olarak kadına uygun görülmüştür. Ders kitaplarının cinsiyet rolleri açısından incelenmesinin sebebi kendini tanımak ve anlamak için önemli yaşam yıllarına denk gelen 2. 3. 4. ve 5. sınıfta eğitimin önemli bir kısmını kapsayan ders kitaplarının hangi bakış açısıyla yazıldığına dikkat çekmektir.

Almanca ve Türkçe ders kitaplarında ortak noktalar olduğu gibi farklılıklarda mevcuttur. Mesela yemek yapmak ve ev işleri her iki ülkenin ders kitabında da kadının sorumluluğu olarak gösterilmiştir. Farklı olan ise Almanca ders kitaplarında evin erkeğinin ve erkek çocukların da ev işlerindeki sorumluluktan pay sahibi olmalarıdır. Kadına yüklenen ev iş yükü almanca ders kitaplarında daha az Türkçe ders kitaplarında daha yoğundur. 
İncelenen Türkçe ders kitaplarındaki kadın ve kız çocuklarının erkek ve erkek çocuklara göre daha geri planda yer aldığını söylemek mümkündür. Buna karşın Almanca ders kitaplarında kadın ve kız çocuklarına erkeklerden daha fazla yer verilmiştir. Bu durumda bu kitaplarla eğitim gören kız öğrenciler kendilerini gerçekleştirmek için örnek alabileceği bireyleri görecek ve kendisini baskılanmış hissetmeyecektir.

Almanca ders kitaplarında öğrencilere hayallerindeki meslekler sorulduğunda kız öğrencilerin oldukça fazla meslek grubu belirttikleri görülmüştür. Kadınların ve kız çocuklarının en az erkekler kadar çeşitli meslek dallarına eğilimli olmaları Almanca ders kitaplarını hazırlayan uzmanların her iki cinsiyete de eşit yaklaştıklarının kanıtıdır. Cinsiyet açısından bu eşitlikçi yaklaşımın sonucu olarak erkek öğrenciler de kendilerini üstün görmeyeceklerdir. Kendisini kadın ve kız çocuklarından üstün görmeyi öğrenmediği için de iş hayatında, sosyal hayatında veya romantik ilişkilerinde kadınları ezmeye çalışmayacaktır. Buna karşılık, Türkçe ders kitaplarına baktığımızda; önemli işlere imza atan, saygınlığı olan, örnek gösterilen bireyler büyük oranda erkektir. Bu durum aynı sınıfta birlikte okuyan iki cinsten biri olan kız çocuklarının kendilerini ötekileştirilmiş hissetmesine sebep olacaktır.

Temel eğitimde kız ve erkek çocukları birbirine üstünlük duymadan sayg1 ve sevgi içerisinde yetiştirmelidir. Bu bilinçle yetişen bireyler gerek sosyal, gerek iş gerekse özel yaşamlarında birbirlerini daha iyi anlayacak ve tolere edebileceklerdir. Cinsiyetçi ayrım beraberinde çatışmayı, huzursuzluğu getirir. Eşitlikçi yaklaşım sayesinde bireyler herhangi bir ayrıma tabi tutulmaksızın her yerde ve her şartta kabul görürler. İnsanlar birbirlerini farklılıklarıyla olduğu gibi kabul etmek zorundadırlar. Ötekileştirici ayrılıkçı, aşağılayıcı yaklaşımlar toplumu böler ve barış iklimine zarar verir. Herkesin bu bilinçle davranması hayatı daha yaşanılır ve sorunsuz kılacaktır. Ders kitapları hazırlanırken bu hususlara dikkat edilmesi gerekmektedir. Zira toplumun şekillenmesinde, eğitilmesinde en önemli araç kitaplardır. 


\title{
EXTENDED ABSTRACT
}

\section{An Overview of Gender in Primary School Text- books Written in Turkish and German as Mother Tongue}

\author{
* \\ Rüveyda Hicran Çebi Kozallı__- Birkan Karg1 \\ Ondokuz Mayıs University
}

The aim of this study is to present the "gender" perspectives and to find out the similarities and differ-ences of the textbooks used in Turkish courses in Turkey and the textbooks taught in German courses in Baden Wüttenberg, Germany. German and Turkish textbooks of 2, 3, 4 and 5. grades, which cover the important age range of identity development, are selected for the study. These are primary school Turk-ish 2.,3.,4. and 5 grade textbooks and Niko Sprachbuch 2-3-4- and 5 grade Deutsch Kombi Plus. The textbooks have been analysed through the items of domestic and nondomestic roles, professional roles and gender roles under five main topics. The results of the research suggest that there have been signifi-cant differences. In Turkish textbooks, there is a remarkable male dominance while in German textbooks it has been detected that texts are unbiased, that the number of visuals of boys and girls are equal, and that sometimes girls play a greater part in the textbooks. Furthermore, in German textbooks, it is found out that girls are supported more in the areas where they might be seen disadvantageous in society. On the other hand, it is concluded that Turkish textbooks do not provide adequate coverage for girls.

In the examinations of books carried out, cooking and doing housework are regarded as the responsibilities of women in both societies. This situation receives more coverage in Turkish textbooks compared to German textbooks. It has been illustrated in Germen textbooks that men and boys take responsibility for housework. More visuals of women and girls take place in German textbooks compared to that of men. The girls reading such books naturally respond to this approach positively. Girls will associate themselves with the characters in the books. They will have 
a place in the society thanks to the roles they are assigned which they find satisfactory.

In german textbooks, when students were asked about the jobs they want to get, they mentioned various grups of professions. This is an ample evidence regarding the fact that the experts preparing textbooks do not treat girl and boy students differently in any way while educating girl students.

Individuals have tendency to make lots of choices during their whole life or sometimes they must do it. While dealing with their prospective job, the area where they will work in, or the works at their own home, they try to choose the things they like or delight. Therefore, the choices should not be restricted with gender. Opposed to the appraised role in female "being a cook", so many men fondly cook and many of the famous cooks are male. Together with this, teacher occupation is presented as a suitable job for women in the both coursebooks in both languages. The reason of analyzing the coursebooks in terms of gender roles is to get to know and comprehend yourself and pay attention to what the point of views of 2nd, 3rd, 4th and 5th graders' coursebooks are written, those of which also cover the important age range of identity development.

The mutual points exist in both German and Turkish coursebooks just like there are differences. For example; in the both course books, cooking or doing chores are presented as a task or responsibility of women. The difference is that the head of home and the boys share the task or responsibility of doing chores in German course books. The assigned chores to the women in German books are lower but it is more intensive in Turkish course books. In German textbooks, when students were asked about the professions in their minds, it was clearly seen that they mentioned many diffrent groups of professions. The fact that women have a tendency to be interested in diffrent types of professions indicate that the educational experts designing Germen textbooks have an equal approach for both genders. As a result of this equalitarian approach in terms of gender, male students will not see themselves superior in any way. As they do not learn to consider themselves superior to women or girl students, they will not attempt to oppress women in their working life, social life or their romantic relationships. On the contrary, when we look at Turkish textbooks, the individuals who put their signature under important success, who are 
higly esteemed and who are introduced as an important figure are mostly males. This is sure to cause girl students, one of the genders in the classroom, to feel isolated.

\section{Kaynakça / References}

Akın, A. (2007). Toplumsal cinsiyet ayrımcılığı ve sağlık. Toplum Hekimliği Bülteni, 26, 1-9.

Asan, H. T. (2010). Ders kitaplarında cinsiyetçilik ve öğretmenlerin cinsiyetçilik algılarının saptanması. Fe Journal: Feminist Critique/Fe Dergi: Feminist Elestiri, 2(2), 66-74.

Tietz, W. M. (2007). Women and men in accounting textbooks. Exploring the hidden curriculum. Issues in Accounting Education, 22, 459-480.

Baştürk, M. (2008). Ders kitaplarının tarihçesi. (Ö. Demirel ve K. Kıroğlu ed.). Konu alanı ders kitabı incelemesi içinde (13-36.)Ankara: Pegem Akademi Yayınları.

Bingöl, O. (2014). Toplumsal cinsiyet olgusu ve Türkiye'de kadınlık. Karamanoğlu Mehmetbey Üniversitesi Sosyal Ve Ekonomik Araştırmalar Dergisi, 3, 108-114.

Çıtak, A. (2008). Kadınların çalışmasına yönelik tutum: Cinsiyet rolü ve sosyoekonomik düzeye göre bir karşılaştırma, Yayınlanmamış Yüksek Lisans Tezi, Ankara Üniversitesi Sosyal Bilimler Enstitüsü,Ankara.

Dökmen, Z. Y. (2004). Toplumsal cinsiyet: Sosyal psikolojik açıklamalar. (1. Bsm). İstanbul: Sistem Yayıncllı.

Dökmen, Z. Y. (2010). Toplumsal cinsiyet sosyal psikolojik açılamalar. İstanbul: Remzi Kitapevi

Eren, Z. (2015). Baba karnım acıkt anne bisikletim bozuldu. Ankara: Favori Kitapevi

Ersoy, E. (2009). Cinsiyet kültürü içerisinde kadın ve erkek kimliği. Fırat Üniversitesi Sosyal Bilimler Dergisi, 2, 209-230.

Esen, Y. ve Bağll, M. T. (2002). İlköğretim ders kitaplarındaki kadın ve erkek resimlerine ilişkin bir inceleme. Ankara Üniversitesi Eğitim Bilimleri Fakültesi Dergisi, 35(1-2), 143-154.

Esen, Y. (2013). Hizmet öncesi öğretmen eğitiminde toplumsal cinsiyet duyarlılı̆̆ını geliştirme amaçlı bir çalışma. Ĕ̆itim ve Bilim, 38,169, 281-295.

Esen, Y. (2007). Sexism in school textbooks prepared under education reform in Turkey. Journal for Critical Education Policy Studies, 5(2), 466-492. 
Gümüşoğlu, F. (2014). Ders kitaplarında toplumsal cinsiyet. Toplum ve Demokrasi Dergisi, 2(4), 39-50.

Gümüşoğlu, F.(1996). Ders kitaplarındaki cinsiyetçiliğin seksen yıllık serüveni. 05.01.2019 tarihinde http://www.huksam.hacettepe.edu.tr/ adresinden erişildi.

Gökçe, O. (2006). İ̧̧erik analizi, Ankara: Siyasal Kitabevi

Heyder, A. and Ursula K. (2015). Ist schulerfolg unmännlich? Wie Geschlechterstereotype den Schulerfolg von mädchen und jungen beeinflussen. Die berufsbildende Schule, 67,5, 178-181.

https://www.emft.fraunhofer.de/content/dam/emft/de/documents/DieMacht-der-Stereotype.pdf

Kalan, Ö. G. (2010). Reklamda çocuğun toplumsal cinsiyet teorisi bağlamında konumlandırılışı''Kinder'reklam filmleri üzerine bir inceleme. İstanbul Üniversitesi İletişim Fakültesi Dergisi, 1(38), 75-89.

Kalaycı, N. ve F. Hayırsever. (2014). Toplumsal cinsiyet eşitliği bağlamında vatandaşlık ve demokrasi eğitimi ders kitabına yönelik bir inceleme ve bu konuya ilişkin öğrenci algılarının belirlenmesi. Kuram ve Uygulamada Eğitim Bilimleri Dergisi, 14(3), 1065-1072.

Kerimoğlu, C. and Gökçe D. (2015). Türkçede cinsiyet görünümleri ve çağrışımsal zihniyet. Türklük Bilimi Araştırmaları,38, 143-178.

Kılıç, L. K. ve Eyüp B. (2011). İlköğretim Türkçe ders kitaplarında ortaya çıkan toplumsal cinsiyet rolleri üzerine bir inceleme. ODÜ Sosyal Bilimler Araştırmaları Dergisi, 2(3), 129-148.

Marshall, G. (2003) Sosyoloji sözlü̆g̈ü. (O. Akınhay ve D. Kömürcü yay.haz.). İstanbul: Bilim ve Sanat Yayınları

Metin, A. (2011). Kimliğin toplumsal inşası ve geleneksel kadın kimliğinin aktarımı. Çankırı Karatekin Üniversitesi Sosyal Bilimler Enstitüsü Dergisi, 2(1), 74-92.

Öngen, B. ve Aytaç, S. (2013). Üniversite öğrencilerinin toplumsal cinsiyet rollerine ilişkin tutumları ve yaşam değerleri ilişkisi. Sosyoloji Konferanslarl, 48, 1-18.

Özaydınlık, K. (2014). Toplumsal cinsiyet temelinde Türkiye'de kadın ve eğitim. Sosyal Politika Çalışmaları Dergisi, 33, 93-112.

Tezcan, M. (2003). Gizli müfredat eğitim sosyolojisi açısından bir kavram çözümlemesi. Türk Ĕ̆itim Bilimleri Dergisi, 1(1), 53-59.

Tietz, W. M. (2007). Women and men in accounting textbook: Exploring the hidden curriculum, Issues in Accounting Education, 22, 459-480. 
Topuz, S. K. ve Erkanli, E. (2016). Toplumsal cinsiyet bağlamında kadın ve erkeğe atfedilen anlamların metafor yöntemiyle analizi. Alternatif Politika, 8(2), 300-321.

Tunç, H. (2014). Toplumsal cinsiyet farklılaşması üzerine sosyolojik bir araştırma: Erkeklerin küpe takması örneği. Uluslararası Sosyal Araştırmalar Dergisi, 7(33), 608-625.

Yogev, Ş. P. (2006). Ergenlerde toplumsal cinsiyetin kazanilması aile, okul ve arkadaş etkisi. Yayımlanmamış Yüksek Lisans Tezi, Ankara Üniversitesi Sosyal Bilimler Enstitüsü, Ankara.

\section{Kaynakça Bilgisi / Citation Information}

Kozallık-Çebi, R.H. ve Karg1, B. (2019). Türkçe ve Almanca ilköğretim ana dil ders kitaplarında toplumsal cinsiyete bir bakış. OPUSUluslararası Toplum Araştırmaları Dergisi, 13(19), 50-74. DOI: 10.26466/opus.544676 